\title{
Demitologizacje
}

DOI: $10.14746 /$ por.2018.2.12

\section{MODIFICATION OF THE SOCIALIST REALISTIC CANON OF UKRAINIAN LITERATURE: PROBLEM OF DEMYTHOLOGIZATION}

\author{
Ulyana Fedoriv ${ }^{1}$ \\ (Львівський національний університет імені Івана Франка)
}

Słowa kluczowe: demitologizacja, socrealizm, kanon literacki, transformacja, modyfikacja Keywords: demythologization, social realism, literary canon, modification, transformation

\begin{abstract}
Abstrakt: Ulyana Fedoriv, MODYFIKACJA SOCJALISTYCZNEGO KANONU REALISTYCZNEGO LITERATURY UKRAIŃSKIEJ: PROBLEM DEMITOLOGIZACJI. „PORÓWNANIA” 2 (23), 2018. T. XXIII, S. 173-186. ISSN 1733-165X. XXI wiek wymaga od współczesnego literaturoznawstwa rewizji wielu warstw ignorowanej od lat kultury ukraińskiej. Do kategorii zapomnianych przez długi czas należał problem kanonu socrealizmu. Dzisiejsze punkty orientacyjne uległy zmianie. Świadczy o tym ukazanie się szeregu literaturoznawczych, kulturologicznych, socjologicznych, antropologicznych badań nad radzieckim. Potrzeba ponownego przeczytania i ponownego przemyślenia literatury socrealizmu jest jednym $z$ kluczowych zadań $w$ dziedzinie aktualnych przedmiotów badań naukowych we współczesnym literaturoznawstwie. Mimo aktywnych badań wymienionego tematu, wciąż pozostaje wiele nieomówionych momentów, w tym problem modyfikacji kanonu socjalizmu oraz osobliwości procesu jego demitologizacji.
\end{abstract}

\begin{abstract}
Ulyana Fedoriv, MODIFICATION OF THE SOCIALIST REALISTIC CANON OF UKRAINIAN LITERATURE: THE PROBLEM OF DEMYTHOLOGIZATION. "PORÓWNANIA" 2 (23), 2018. Vol. XXIII, P. 173-186. ISSN 1733-165X. The XXI century demands from the modern literary criticism a revision of many strata of the Ukrainian culture that have been ignored for years. For a long time, the problem of Socialist Realism has belonged to the category of forgotten. Modern landmarks have changed. This is evidenced by the publication of a number of literary, cultural, sociological, anthropological studies of the Soviet times. The need to re-read and re-think socialist realistic literature is one of the key tasks in the field of topical objects of the scientific study in modern literary criticism. However, actively exploring this topic, there are still many
\end{abstract}

1 E-mail: ulyana.fedoriv@lnu.edu.ua 
ambiguous moments, including the problem of modification of the socialist realistic canon and the peculiarities of the process of its demythologization.

The socialist realistic canon is a sophisticated and inhomogeneous phenomenon. It imposed upon culture and art ready schemes of analysis and reflections upon the reality. Starting from the 1930's texts which followed the government rules gained typical structure, predictability and recognizability, turning literature into mass production of homogeneous "art" product. The task of such a governmental experiment was both to change the world and change the way to perceive reality. Aestheticized reality falsification, clear domination of "ideologic" and "totalitarian" in the sphere of culture, formation of socialist realistic theory as a process of art awareness politization - these are those formants which defined evolvement and functioning of the socialist realistic canon of Ukrainian literature.

After Stalin's death, the government announced a focus on "liberalization" of social life and the so-called "literature renovation". The change in the picture of the Soviet world also required corresponding processes in the socialist realistic canon of Ukrainian literature. The need to "talk about something else" and "in a different way", going beyond the main plot, "limited" widening of the canon frameworks can be considered a specific governmental experiment for holding its influence in a social-cultural sphere. It is obvious that the party consciously chose a new (needed!) course concerning the interpretation of universalism of certain Soviet myth in the culture of the totalitarian society which had basic meaning as archetype constructions, projected into the society's self-organization. Such a process encouraged a range of new or rethought dominants of socialist realistic texts.

One of the most prominent layers where changes occurred, was the g e $\mathrm{n} \mathrm{r} \mathrm{e} \mathrm{-} \mathrm{t}$ h e matical one. Such a transformation can be considered a compromise between an internal need of socialist realistic canon widening and government regulations concerning "truthful, specific-historical reflection of reality" (Pervyi Vsesoyuznyi Syezd Sovetskikh Pisateley 21). The most representative in a given context is the phenomenon of fictional prose (khymerna proza ${ }^{2}$ ) which can rightly be called a non-socialist realistic notion in a closed ideologically regularized socialist realistic system. Although fictional prose was not a total notion inside a government project, in a way it corrected the text-creation canon of Socialist Realism, trying to develop new poetic practices, creating philosophical-ethical subtext, bringing intellectual strain, strengthening associativity, developing lyrical stories, widely using myths, elements of fantasy and fairytale, irony, funny elements, parody, etc. What-

2 For more information on the influence of fictional prose on the process of socialist realistic canon deformation in the Ukrainian literature, see Fedoriv. Ulyana. Sotsrealistychnyi kanon v ukrainskii literaturi: mekhanizmy formuvannia ta transformatsii: rukopys dysertatsii na zdobuttia naukovoho stupenia kandydata filolohichnykh nauk. Lviv, 2016. 227 s. Web. 3.06.2016. <http:/ / www.lnu.edu. ua/thesis/fedoriv-ulyana-mykolayivna/> 
ever was the reaction of the criticism on similar experiments in literature, including the search of arguments concerning "wrecking" of such widening of socialist realistic scheme and a statement about a "hopeless step back, which pushes art towards decorative imitation, sharp allegories, cheap sarcastic comments" (Kubilyus 56), but still fictional prose became a specific artistic bridge from the decanonization phase in which the canon widens and loses its necessity to a post-canonical phase where the canon is in a stage of decay.

However, a genre-thematical transformation of the canon was not limited to fictional prose. There also appear other "novelties" inside Socialist Realism which was a consequence of a certain modification of the government regulations. Such a new topical unit were texts dedicated to e cology and the e cological catastrophe. Of course, research on ecological problems was not the writers' direct task. Here it was more about the problem of moral and social values of a person, responsibility in both the microworld and the macroworld. Thus, appear such works as The Last Island by Yurii Mushketyk, Hello, Prypiat! by Oleksandr Levada, Bryhantyna by Oles Honchar, Rosava by Vitaliy Lohvynenko, Hileya by Mykola Zarudnyi, Goldfish Birthday by Ivan Bilyk, Cathedral by Oles Honchar, and others ${ }^{3}$. Although main ideological dogmas remain the same, we still see certain differences in such texts. It is an attempt to create distance from the government control as far as allowed, efforts to "note down" the topics the government was not comfortable with. In these works one can feel the inextricable connection of "nature" and "human" origin, synthesis of problems pf environment ecology and soul ecology, actualization of existential texts' sounding. Such a combination of an ecological topic with a philosophical one can be seen in the novel by Oles Honchar Cathedral. Following the clear scheme of the "master plot" (K. Klark) which was defined by the government using the whole "artistic" armory of the Soviet literature, the writer saves the text in socialist realistic "scaffolds". However, the picturing of the cathedral and events around it allow the reader to also find something non-socialist realistic in the work. That is why it is not surprising that Oles Honchar is quite often named "non-dogmatic representative [...] of socialist realistic canon, he aspired to widen the Soviet literature both thematically and formally, had his own style, dared to implement national and patriotic ideals, had his own view on the Soviet humanism, tried to be a writer-intellectual and a philosopher" (Hundorova 204). The author, apart from ecological problems, was interested in the problem of spiritual degradation of a person, a problem of preserving the historical landmark-memory. Thus, Marko Pavlyshyn points out: "Notion "Loboda" is connected in the novel with polluting of Dnipro, killing of wild boars, flooding of Dnipro flood lands. Moral appraisal of Loboda's deeds transfers

3 To be fair, it is worth noting that the choice of environmental topic was not a phenomenon of the Ukrainian literature exclusively. This tendency was characteristic of other USSR national literatures too. In particular, V. Rasputin's Farewell to Matyora, V. Shuksyn's Lyubaviny, A. Solzhenitsyn's Matryona's Place, B. Mozhayev's Alive, etc. should be recalled too. 
also on phenomenon of ecological and cultural destruction: it is not just dangers or something uncomfortable, but blames before mankind future and a single organism, to which both a person and nature are included" (Pavlyshyn 50).

However, it is worth mentioning that despite Oles Honchars' attempt (conscious or unconscious) to, in a way, "humanize" a socialist realistic scheme, one should not forget about irrecoverable losses, from which suffered then existing culture as a result of the government regulations. Yurii Shevelov mentioned this exact fact in an article "Gains and losses of the Ukrainian literature: On O. Honchar's novel "Tavriia"", emphasizing on the problem of "deintelligence" of the Ukrainian literature: "Talking about the author's talent they talk even more about the main loss of the Ukrainian literature under the USSR - the loss of culture". These are bitter words, scary words, but they have to be told. The Ukrainian literature in the USSR is not only pushed back on 70 years, - it does not even have that level of culture it had then [...]. The absence of culture is revealed not only in the absence of style, in the loss of style understanding" (Shevelov 251).

In the field of a new topical picture of Socialist Realism, new heroes appeared. They pushed heroes-workers, heroes-villagers, heroes-warriors to a periphery. But it is worth mentioning that both working (Ordinary Life and White Flame by Vadym Sobko, The Mellow Chime by Yurii Zbanatskyi, and others) and military (The Goal by Oleksandr Syzonenko, Wild Honey by Leonid Pervomaiskyi, Person and Weapon and Tronka by Oles Honchar, Europe-45 and Europe West by Pavlo Zahrebelnyi) topics that were so much tolerated by the government, did not disappear anywhere. New "village" epic literature also functioned actively (Position by Yurii Mushketyk, The Four Fords by Mykhailo Stelmakh, Poem of the Sea by Oleksandr Dovzhenko, The Father's House by Vadym Kozachenko, Above Dnipro by Oleksandr Korniichuk, etc.). But a hero as a person of a planetary character comes to the fore, he is ready to change himself and change the world (however, it is all for the sake of the state!). "All-encompassing view of the planet, courageous enters of the international arena, epicism of people's characters, psychological penetration in individual fates" (Fashchenko 48) - these are the "novelties" of the old scheme. The psychology of a simple person, often his/her evolvement and growth, life challenges and their overcoming - these are the points which are actualized in the frameworks of the anthropological project of a "new man": "Soviet people changed and grew up together with those enormous transformations, which drastically changed the USSR's face. Thus, the noble task of the Soviet literature, including the Ukrainian one, - to show those new people to the whole world - simple people, ordinary, humble, but at the same time courageous, heroic, true history makers" (Istoriia ukrainskoi literatury 1957: 34). Unfortunately, such hero still remained to be a cog in the wheel of the totalitarian machine who had to carry out new party's tasks, because, as Valentyna Kharkhun claims: "New man - is just an ideologeme, which needs a representative formula, which would make it noticeable and persuading, 
and this would enable implementation of the totalitarian anthropological project" (Karkhun 290).

In the texts from the second part of the $20^{\text {th }}$ century we observe a process of the transformation of the anthropological concept of a "new Soviet man" due to dispelling of certain myths about universalism of a homo soveticus. For instance, the status of a mentor changes. Now it is not always interpreted as an authority and a moral example. Quite often he changes his status of he ro for antihero, and later transforms into an enemy. Adding to a text a new type of enemy of the Soviet people - a "social climber", an "opportunist", a "nonprofessional" - it is an attempt to artistically write into the literature socialist realistic efforts to be, in a sense, with a "human face", point out to the Socialist Realism "humanism". The examples of such antiheroes could be Loboda (Cathedral by Oles Honchar), Odynets (White Shadow by Yurii Mushketyk), Prytula (The Last Island by Yurii Mushketyk), who are those people that never feel "pangs of conscience, or suffer from evil deeds" (Mushketyk 501-502), they are those who "create internal philosophy and try to calm themselves down with it", for whom "the bigger a dirty trick is, the more difficult the "philosophy" is" (Mushketyk 501-502). It is worth mentioning that in the times of the "thaw" the transformation of an enemy's character occurred also on the social-class level: instead of a "capitalist" or a "money grubber" we have a "reseller" or a "tradesman". Lev Gudkov concisely noticed a transformation "from early black-and-white caricature-poster fat men capitalists in top hats, with a sack of dollars in a hand to Uncle Sam - emblematic representatives of big business, the Pentagon, generals, and others." (Obraz vraga 57). But there also appear enemies of a different kind - "criminals", "alcoholics", "speculators", "idlers", "hooligans", "spongers", "egoists", etc. These are so-called "internal enemies", who formed the a n t i w o r ld in conditions of the Soviet society, which needed immunization from such antiheroes, and such means of protection became directive provisions concerning the fight against those criminals (since 1961 idleness was punished by criminal accountability), stigmatization (reprimands at work, judging meetings of staff, fines in the form of working days, bonuses annulment, etc.) and public awareness campaigns (in particular, in Literaturna Hazeta there was a constant satirical column about idlers, spongers, resellers, capitalists, who were pictured in expensive clothes, in expensive cars, at posh parties (Darmoiedy).

As it was mentioned above, a pantheon of Soviet heroes changed in the second part of the $20^{\text {th }}$ century. The state needed an altered iconostasis, because death of intellectuals was no longer needed, since the country should have been rebuilt not only with hands, but also with a head, so a new type of hero appears - a s cie ntist, a researcher, an inventor. If a typical hero for the 1930's was a very young person, then starting from the 1940's we could see in texts more mature heroes (both by age and by status). These are people, who have already gone through the government "correction" and in compliance with the party regula- 
tions are ready to "improve" the Soviet world: "Artistic-psychological analysis of a "person at war" now should have served also to solve a problem of a "person after war", a person in work and creativity, in search of himself/herself, in his/ her natural desire to feel wholeness of conquered happiness" (Istoriia ukrainskoi literatury 1971: 57). Attention to a Soviet person of a new formation encouraged appearance of a topical group of texts, dedicated to a problem of a y o ung person's evolve ment. In particular, one should mention such works as Idol by Anatoliy Dimarov, Cuckoos are calling and Greet me, friends! by Yurii Zbanatskyi, The Silver Ship by Vadym Sobko, Yurko Kruk by Petro Kozlaniuk, A Day Flies Above Us by Yurii Mushketyk, From the Point of View of Eternity and Let's Come to Love by Pavlo Zahrebelnyi, and others. If before "human material" went through correction and gained a status of a "new man" under strict supervision of either symbolic Father (Stalin), or older party brother-mentor, then in the phase of the canon loosening we have a different type of hero: "These are such characters of people, who are constantly developing, "renewing" internally, feeling on their skin great truths of that time, characters of people with rich and complicated internal life" (Istoriia ukrainskoi literatury 1971: 34). Thus, in socialist realistic works appears a "hero in doubt", a "hero at a crossroad", a "positive hero of our days", a "hero-builder of his own life" (Konstantynova).

Actualization of a new type of hero is also connected with a problematic-topical canon's modification, in particular with appearance of a topic of scientific and technical revolution. Thus, appears another location of the government plan of building a "glittering future". Plants, factories, collective farms are changed by scientific research institutes, laboratories, training rooms, etc. A hero-scientists focuses on new tasks - help in development of the postmilitary state, scientific and technological advance, improvement of science and technology, entering of the Soviet scientific elite in the world context, etc.: "As a scientist he understood, and understood somehow universally, dialectically, flowingly that the world depends to a certain extent on his test tubes, his electric microscope. This whole world. Meadows, forest, people. That he himself is not only humus, clay, but also a demiurge" (Mushketyk 388). The aim of then existing government - was to project a new type of hero (even a super-hero!), who is an embodiment of a professional-scientist, conscious citizen and deeply moral personality: "A person enters the orbit of the main concerns not only from the point of view of how s/he works at production, but also from the role of the citizen and human dignity" (Zahrebelnyi 489).

Actualization of a so-called "socialism with a human face" encouraged appearance of such heroes as a r t is ts (Performance by Yurii Drozd, From September's Height by Volodymyr Yavorivskyi, Come back home by Yurii Mushketyk, and others), scientists (White Shadow and Blood Drop by Yurii Mushketyk, Acceleration by Pavlo Zahrebelnyi, Time for Hopes and Achievements and Soldiers Without Uniforms by Natan Rybak, The First Drops of Rain and The Silver Ship by Vadym Sobko, Alma ma- 
ter and Above the Planet by Yurii Bedzyk, Chain Reaction by Volodymyr Yavorivskyi), te a c her s (The Mellow Chime by Yurii Zbanatskyi, The Frogs' Emperor and Finding for the Whole Life by Oleksii Ohulchanskyi, The Favourite Book and The Golden Medal by Oles Donchenko, Weirdos by Borys Komar, The Burdock King by Vasyl Fiyalko, The Cut Desk by Oleksandr Kopylenko, and others). The last-mentioned block works about teachers - is closely connected with literature about and for children. The Soviet system needed a "new man" to build "radiant future", thus significant part of the "biographic project" was picturing of childhood, which aim was to show a Soviet child not only as an archetype, but as a certain kind of biography, that was created according to strictly written schemes and canons (specific similarity to hagiography $)^{4}$. "Correction" of a child into a "new man" became one of the main tasks of the totalitarian regime. It is noteworthy that in socialist realistic texts a border between childhood and adulthood is blurred: Soviet kids do not live in the period of childhood as a goal in itself, since they fell an "internal need" to help the country, to be useful for the community, conduct a fight with "strangers". In the 1930's-1940's literary representation of a child was limited by military characters of a "child without childhood" and characters of "work heroes". However, in the second part of the $20^{\text {th }}$ century the government "allowed" childhood that was strictly regularized and limited by governmental resolutions, but "different" one (according to the official version - a "happy" one) (Miy uchytel; Shchaslyvymy dorohamy). Children are no longer "guerillas", "soldiers", "workers", but "pupils", "pioneers", "young naturalists", etc. They have a chance to "come in handy", "feel like super-heroes", "live through something fantastic in reality", etc. These are people of a new generation, with a well-developed imagination, intellectually honed, ready to break with templates and standards. Thus, in the Vsevolod Nestaiko's work we read: "After he had finished reading heroes continued to live and act in Lesyk's imagination. Every time more and more new adventures occurred. And together with that plots from different books intercrossed. Tom Sawyer and Huckleberry Finn ended up in Lilliput, met Captain Nemo, the Count of Monte Cristo, together with Gavroche appeared on barricades of revolutionary Paris, etc." ${ }^{\prime 5}$ (Nestaiko 144-145). Often a character of a young hero has fairytale-fantastic traits and there are mythical-fairytale or demonic characters in the text. From

4 Look.: Dobrenko. Evgeniy. “Sotsrealizm i mir detstva”. Sotsrealisticheskiy kanon. Red. Kh. Gyunter. E. Dobrenko. Sankt-Peterburg: Akademicheskiy proekt, 2000. S. 31-40;Fedoriv, Uliana. "“'"'"'"'Nova liudyna"'"'"'"': kanonizatsiia radianskoho dytynstva". Literatura. Dity. Chas. Lviv: Tsentr doslidzhennia literatury dlia ditei ta yunatstva, 2016. S. 195-206; Hohokhiia, Nani. Dytynstvo u totalitarnomu suspilstvi: "virni lenintsi" radianskoi Ukrainy u 1930-kh rokakh. Ukraina Moderna. Web.17.08.2015. <http://uamoderna.com/md/gogokhia-childhood-ussr-1930s; Socialisation Through Children's Literature: The Soviet Example. Red. Felicity Ann O'Dell. New York and London: Cambridge University Press, 1978. 278 pp.

5 By the way, Vsevolod Nestaiko - one of not so many authors who were and still are in the active canon of Ukrainian children literature. Despite the activity of the regulated system of Socialist Realism inside, the writer managed to find such universal forms, which would "speak" in spite of various political factors. Since 1979 there has been a decision of International Children Book Council about 
this point, adventures became a form of children's knowledge if the world and his/ her self-knowledge, a mechanism of going from one reality into other, possibility to try and out-grow themselves in an adventure-game. But the picturing of a "happy childhood" had a false mirror effect and brought up an internal opposition in some writers who worked in the frameworks of state field of literature but could not accept the socialist realistic identity. There are published works which distort the scheme of "ideal Soviet childhood", actively supporting the process of the regime's myth demythologization about "happy Soviet childhood". Thus, there appear $\mathrm{f}$ a therless children who take roles of guardians and breadwinners, be g gars and homeless, disabled, and malnourished children (Hryhir Tiutiunnyk Before Thunder, On the Roll, Sieve, Sieve..., Yevhen Hutsalo Seed from the Nut, About Frozen Kalyna, Blind Sen ${ }^{6}$.

Not less interesting is the problem of a literary representation of the $\mathrm{w}$ o $\mathrm{m}$ a $\mathrm{n}$ ch a r a cter in the Ukrainian socialist realistic literature of the second part of the $20^{\text {th }}$ century, an issue of a woman's private space, and, actually, gender diversity of heroes. In the phase of active usage of a canon hero-warriors, hero-workers or hero-party leaders were gender neutral ${ }^{7}$. The rejection of topics about love, physical pleasure, fight for happiness and dreams, because «interest in psychology in literature can «blunt class consciousness» of a proletarian writer, turning him into an «objective observer and unbiased judge» (Carlton 341) - these were the norms which were updated in the socialist realistic canon of the active phase. Here we observe a situation of absolute marginalization of the physical and a total exclusion of intimacy from the field of Soviet daily life, which was considered «detrimental» in the regime's project of creating a «happy future» (Sadowski 24.). We can rarely find in texts descriptions of private space or personal interior items, etc. Events mostly take place in the frameworks of plant-factory territory, and hero's connection with a topos of home and family is almost lost. Thus, a Polish researcher Carolina Blekharchuk in an article The body in the service of socialism points out: «For the Bolsheviks release of a person from a family circle had not only ideological meaning - since

including "Toreadors from Vasiukivka" in Special Honored List of H. C.Andersen. Today V. Nestaiko's works are part of school curriculum for the Ukrainian literature.

6 In the context of the given research one should pay attention to another problem - the influence of the canon of children socialist realistic literature on the realization of the role and place of a child in the modern society. Thus, it is important to emphasize on the problem of traumatic memory and shadow of the totalitarian past in modern canon-creation process, in particular, concerning literature representation of a child character. Look.: Postkolonializm. Heneratsii. Kultura / ed. T. Hundorova, A. Matusiak. Kyiv: Laurus, 2015. 336s.; Kachak, Tetiana. "Podolannia tematychnykh tabu u suchasnii ukrainskii prozi dlia ditei ta yunatstva: postkolonialna praktyka". Naukovi pratsi: naukovo-metodychnyi zhurnal. № 228. T. 240, 2014. S. 51-58.

7 Look.: Kelli, Katriona. "”Hochu byit traktoristkoy!". (Gender i detstvo v dovoennoy sovetskoy Rossii)". Sotsialnaya istoriya: Zhenskaya i gendernaya istoriya. Moskva: ROSSPEN, 2003. S. 385-410; Stiazhkina, Olena. Henderni vymiry radianskoi povsiakdennosti 1960 - seredyny 1980-kh rr. Kraieznavstvo. 2010. № 3. S. 214-223. 
a person had to get rid of private life for the sake of community, a family was a danger for this community. It was considered as a lair of dangerous ideas, bourgeois traditions and relations [...]. The gradual finely liquidation should have happened because of abovementioned sexual revolution, and also a concept of collectivization of all children, transferring elements of family life into public sphere (factory and city canteens, laundries, nurseries)...» (Blecharczuk 115-116).

But we should rightly point out that in the second part of the $20^{\text {th }}$ century the problematic-topical field became a little bit wider, appeared characters of women with new social roles - a woman-companion, ideal as sistants, who dedicated their lives to their husbands (Yurii Mushketyk White shadow), a w o ma n-s e d u cer and a w o ma n-lover (Pavlo Zahrebelnyi From the Point of View of Eternity; Vasyl Zemliak Swan Flock), a s p or t s w o m a n (Vadym Sobko Lykhobor), etc. Dispelling of a myth about a Soviet woman as a «one-woman army», actualization of a woman dominant, winning back of the traditional gender identity for a woman-hero - these are the typical features of the Ukrainian literature of the second part of the $20^{\text {th }}$ century.

General tendencies in then existing literature - text liricization, deepening of the philosophical style in writing, increase of attention to the person, his/her authenticity and self-realization - also concerned the h i s t o rical prose genre. It is worth mentioning that here we talk about two processes - demythologization of Soviet political myths and remythologization of the Ukrainian heroic past. The historical topic has always held a separate place in the text-creating canon of Socialist Realism, since in Socialist Realism, which was completely future-oriented, the past was absolutely depreciated, and could not be a role model. Moreover, the state turned out to be a monopolist in a sphere of «historical-truthful» depicting the past as: «Soviet historical novel, film, play, picture is a story without past. Here, however, Socialist Realism did not invent anything in the historical genre. Other thing is important: the state monopoly of history and past defined a status of Soviet historical genre, in particular, of historical novel as a state novel in all senses. Its «realistic» texture... its original concept, its pathos itself was defined by the state. It is not strange that the state was its main hero. But it also was a romance of the state with history, natural attempt to «tame» past. History and literature met each other in area of Soviet culture» (Dobrenko 889). The concept of a historical novel, suggested already in 1934 by Georgiy Lukach who tried to combine Hegel's integrity and Marx's split of the world, faced a complete failure (Lukach 1935; Lukach 1994). The inability to connect historicism with party affiliation and express a formula typical for the socialist realism characterised by a «true, specific-historical depicting of reality in its revolutionary development» (Pervyi Vsesoyuznyi Syezd Sovetskikh Pisateley 21) pushed historical prose to the periphery. Only some topics, beneficial for the regime, were shown in the socialist realistic canon, which led to a depreciation of others: «Monumentalist depicting of past rules over other means of historical description, in other 
words above antiquarian and critical, but past itself suffers from it: whole significant chapters of past are forgotten and neglected» (Nietzsche 161). For a text to become «historical», it has to be a "party» one. For distracting thoughts about artificialness and customization of party spirit in times of liberalization, they tried to give it traits common to humanity, aspiration to objective truth, and interpreted it as an «esthetic quality» (Kunitsyn 273) (esthetic category) and as a «display of creative freedom» (Kunitsyn 273). The construction of memory policy was one of the priority tasks of the contemporary regime. Thus, a leader of the party was a history maker who defined the «main plot» of historical prose in the socialist realistic canon, built its idea-topical and genre hierarchy and defined historical e ne mies and he roes. The creation of a Soviet novel (including a historical one), according to Katerina Klark, was similar to a ritual: «...a procedure of a novel's creation started to remind a Medieval procedure of icons' creation. A Soviet novelist has to copy not only some [...] characters and relations between them, but also has to organize a novel's conception according to a template» (Klark 27). The works that were «exemplary» and «historically-true» for the Soviet regime included Ukraine Roared by Petro Panch, Pereyaslav Council by Natan Rybak, Khmelnytskyi by Ivan Le, Sviatoslav and Volodymyr by Semen Skliarenko, Semen Palii and Haidamaks by Yurii Mushketyk, People Catchers by Zinaida Tulub, and others. In «exemplary» historical prose itself one can trace one more specifically Ukrainian trait of Socialist Realism - an idea of an «older brother kind of friendship» with the "great Russian people» (this can explain a great number of works dedicated to glorification of the Pereiaslav agreement).

However, it is worth mentioning that despite the ideological pressure, certain changes occurred in the Ukrainian literature in the second part of the $20^{\text {th }}$ century. Writers tried to use a new way to model heroic, and at the same time, tragic events of the Ukrainian past, often revealed historical falsifications, actualized depreciated topics of the Ukrainian history. So, the appearance of such works as Janissaries (Mallows) by Roman Ivanychuk, Arei's Sword by Ivan Bilyk, Scythian Odyssei and Marusia Churai by Lina Kostenko, Wonder, Yevpraksiia and First Bridge by Pavlo Zahrebelnyi were an unconventional phenomenon, a factor which influenced the shattering of the socialist realistic canon. It is worth mentioning that a specific trait of understanding historical topics and plots of the contemporary prose is a connection with philosophy, interest to moral-ethical problems, and existential notes in a text. Thus, the concept of «thinking history» (Ilnytskyi 246) can be considered defining in the contemporary historical prose. The problems of the past were interpreted as extremely important, because they were projected on modern events on which the nation's fate depended. Choosing a philosophical-existential understanding of the past, writers tried to start a dialogue with the reader about the past and the present, about historical memory and historical amnesia, about oblivion and responsibility, etc. New heroes also appeared: chronichlers (Roman Fedoriv Father's Lamp), princes-thinkers (Semen Skliarenko Volodymyr), philosophers (Pavlo 
Zahrebelnyi Wonder). Such a re-opening of historical prose can be interpreted as an attempt to return the Ukrainian history through artistic words (especially the history of Kyivan Rus which was included in the history of Russia), as winning back literature space about its own «crossed out» or «forgotten» past.

Despite a clear «measuring» of not-socialist realistic, apart from the above mentioned novel types in the frameworks of fictional prose (novel-parable, novel-confession, novel-metaphor, novel-automimicry, novel-polemic, novel-report, novel-hyperbola, etc.), a genre of a «story» appears in the Ukrainian literature (Village Stories, Town Stories, Gods for Sale. City Stories by Anatolii Dimarov), a tale in short stories (Singing Crib of Willow by Yevhen Hutsalo), a family novel (His Family and Idol by Anatolii Dimarov), a confessional novel (White Clouds by Oleksii Syzonenko), a tale-memory (Sun Blossomed in a Grove by Yevhen Hutsalo) a novel-ballade (House on a Top by Valerii Shevchuk), a tale-ballade (Duke's Mountain by Yevhen Hutsalo), a fantastical novel (Who are you?, Amrita's Vase, Star Corsair by Oles Berdnyk, Big Day of the Incas by Yurii Bedzyk), autobiographical genres (The Third Troop by Volodymyr Sosiura, Ivan's Cranes by Ivan Chendei, The Geese and Swans are Flying by Mykhailo Stelmakh), etc.

A u tobiographical prose became especially interesting in a given context, since during the whole time of socialist realistic canon there was a statement about how fruitless autobiographic genres were, because they required self-analysis, using a psychological litmus, true estimation of events which was unacceptable for the regime,since «a writer of Socialist Realism is oriented (or at least supposed to be oriented in compliance with official requirements) towards the reception of an infantile, immature, mostly not educated reader «from the common people»; for such recipient an author is always in a role of a wise teacher, and has no right to show his/her own problems and doubts» (Konstankevych 358). Such genres of Socialist Realism feature disassociation and interobjection. They made autobiographic texts non-autobiographical, in other words, the writing in them was regularized, and a «biography» was not «lived through», but strictly «constructed»: «Here we talk about a more complex and deeper ambiguity connected with a difficult internal conflict of a not regular mass person who is not only a passive object of a given reality, but also an active creative individuality who is able to form this reality creatively. We talk, thus, about a person who him/herself, voluntarily and sincerely chose the Soviet Communistic ideology, somehow agreed to it with his/her human and national nature, and continues to be sincerely loyal to this ideology, despite its historical metamorphosis. But at the same time this person is and tries to be, let us say, «true to him/herself», sincerely believing or trying to believe in harmony of his/her nature with the ideology, and that is why s/he not only do not hide with this nature, but constantly shows it in a naïve way» (Hryshko 9). Autobiographic works of the period of Socialist Realism can be interpreted as such where a «split of own biography» is shown (Hryshko 294). It is clear that such texts are supposed to 
be connected with memory, however, ideological parameters of Socialist Realism limited its action, subjected it to the ruling ideology and only a weakening of the regime's tension would enable to widen its autobiographic space («in the widest sense of a place of personal memory» (Starovoit 60) and autobiographic field («confessional magnetism, which leads us to them» (Starovoit 60)). Such attempts to «write in» their true ego-stories became works The Third Troop by Volodymyr Sosiura, Blue Child by Anatolii Dimarov, Moon of the Blue Horizon, Ivan's Cranes, Fairytale of White Frost by Ivan Chendei, On Kalyna Bridge by Petro Panch, The Enchanted Desna by Oleksandr Dovzhenko, The Geese and Swans are Flying by Mykhailo Stelmakh), etc.

So, a detailed analysis of the Ukrainian socialist realistic literature gave the possibility to trace the regime's manipulations in the acts of canonization/decanonization based on the repartition of power in the literature. The consequence of such internal interferences was building of the canon not as a representative set of texts, but as a hierarchic list forced by the regime. Research of the socialist realistic canon from an axiological point of view helped to understand «cultural grammar» of the Soviet people as an ideologically constructed society and define its main symbolic forms of expressing cultural senses of the Soviet reality.

In the Soviet society, culture and art were never imagined beyond politics, and politics - beyond the ideology. Thus, we can consider the regime's ideology to be the main factor of the socialist realistic canon's formation. Its aim was to bring individual creativity under control of mindset regulations and political goals. In fact, the domination of the ideological factor on culture and literature led to the aestheticization of daily life in Socialist Realism and the creation of a fake world, theatricalization and ritualization of life. So, Socialist Realism is interpreted as an artificially modeled regime's project in a sphere of culture and literature which for the sake of monopolization of power on all levels and strengthening of a new Soviet identity (homo sovieticus) had a goal to create a monopolistic system with strictly written rules, detailed schemes, specifically developed characters, understandable for a mass Soviet reader.

Evgeniy Dobrenko, while researching Socialist Realism, calls it a representational project, where the literature plays the role of a specific factory of producing ready products which do not need to be «savored», but only «taken» and «consumed». The aim of such production is building of a «new man» and a «new society», constructing a right reality. However, reality is a changeable category. It can transform and modify itself. Thus, relative liberalization of social processes in the second part of the $20^{\text {th }}$ century encouraged the appearance of new topics and genres, new heroes and enemies, complicated text's poetics, going beyond frameworks of the «master plot». The concept of «methods pluralism», interpreting Socialist Realism as an «open artistic system» and the idea of "Socialist Realism without margins» - all influenced the system's shattering from the inside. The inability to preserve dogmatism and normativity in the literature, use the socialist realistic doctrine to a live 
literature process beyond the totalitarian ideology led to the demythologization of the main regime's postulates in a sphere of culture and gradual decay of the socialist realistic canon as an artificially constructed regime's project.

\section{BIBLIOGRAFIA}

Blecharczuk, Karolina. „Ciało w służbie socjalizmu. Cielesność i życie intymne w pierwszym dziesięcioleciu istnienia Związku Radzieckiego". The Human Body in the Socialism Service. Corporeality and Sexuality in the early years of USSR. Tematy z Szewskiej "Errotyzm". 2 (16) (2015). S. 108-119.

Darmoiedy. 1960. Web. 16.11.2015. <http://www.oldgazette.ru/litera/10051960/index1.html>

Dobrenko. Evgeniy. „Sotsrealizm i mir detstva”. Sotsrealisticheskiy kanon. Red. Kh. Gyunter. E. Dobrenko. Sankt-Peterburg: Akademicheskiy proekt, 2000. S. 31-40.

Dobrenko, Evgeniy. «Zanimatelnaya istoriya: istoricheskiy roman i sotsrealisticheskiy realism». Sotsrealisticheckiy kanon. Red. H. Gyuntera, E. Dobrenko. Sankt-Peterburg: Akademicheskiy proekt, 2000. S. 874-895.

Fashchenko, Vasyl. Heroy i slovo: problemy, kharaktery i poetyka radianskoyi prozy 80-kh rokiv. Kyiv: Dnipro, 1986.

Fedoriv, Ulyana. „»Nova liudyna»: kanonizatsiia radianskoho dytynstva”. Literatura. Dity. Chas. Lviv: Tsentr doslidzhennia literatury dlia ditei ta yunatstva, 2016. S. 195-206".

Hohokhiia, Nani. „Dytynstvo u totalitarnomu suspilstvi: «virni lenintsi” radianskoi Ukrainy u 1930-kh rokakh". Ukraina Moderna. Web. 17.08.2015. <http://uamoderna.com/md/gogokhia-childhood-ussr-1930s.

Honchar, Oles. „Sobor”. Tvory [V 7 t.]. Oles Honchar. T. 7. Kyiv: Dnipro, 1988.

Hryshko, Vasul. "Sertse druhoho Volodky i zaboronena liubov”. Zasudzhene i Zaboronene. Volodymyr Sosiura. Red. V. Hryshko. New-York: Amerykansko-Ukrainska Presa, 1952. S. 7-39.

Hundorova, Tamara. Kitch i literatura. Travestii. Kyiv: Fakt, 2008.

Ilnytskyi, Mykola. Liudyna v istorii: suchasnyi ukrainskyi istorychnyi roman. Kyiv: Dnipro, 1989.

Istoriia ukrainskoi literatury [V 2 t.]. T. 2. Kyiv: Vydavnytstvo AN URSR, 1957.

Istoriia ukrainskoi literatury [V 8 t.]. T. 8. Kyiv: Naukova dumka, 1971.

Kachak, Tetiana. „Podolannia tematychnykh tabu u suchasnii ukrainskii prozi dlia ditei ta yunatstva: postkolonialna praktyka". Naukovi pratsi: naukovo-metodychnyi zhurnal. № 228. (2014). S. 51-58.

Karlton, Gregori. „Na pokhoronakh zhivykh: teoriya "zhivogo cheloveka” i formirovaniye geroya v rannem sotsrealizme". Sotsrealisticheskiy kanon. Red. Kh. Gyunter. E. Dobrenko. Sankt-Peterburg: Akademicheskiy proekt, 2000. S. 339-351.

Kelli, Katriona. „«Hochu byit traktoristkoy!» (Gender i detstvo v dovoennoy sovetskoy Rossii)”. Sotsialnaya istoriya: Zhenskaya i gendernaya istoriya. Moskva: ROSSPEN, 2003. S. 385-410.

Kharkhun, Valentyna. Sotsrealistychnyi kanon v ukrainskii literaturi: heneza, rozvytok, modyfikatsii. Nizhyn: Hidromaks, 2009.

Klark, Katerina. Sovetskiy roman: istoriya kak ritual. Per. M.A. Litovskoy. Yekaterinburg: Izdatelstvo Uralskogo Universiteta, 2002. 


\section{ULYANA FEDORIV, MODIFICATION OF THE SOCIALIST REALISTIC CANON...}

Konstankevych, Iryna. Ukrainska proza pershoi polovyny XX stolittia: avtobiohrafichnyi dyskurs. Lutsk: Vezha-Druk, 2014.

Konstantynova, Maryna. Peremeny v russkom literaturnom pole vo vremia i posle perestroiki (1985 - 1995). 2011. Web. 7.12.2015. <http:// dare.uva.nl/record/314795>

Kubilyus, Vitautas. „Formirovaniye natsionalnoy literatury - podrazhatelnost ili khudozhestvennaya transformatsiya". Voprosy literatury, 1976. № 8. S. 21-56.

Kunitsyn, Georgiy. Yeshche raz o partiynosti khudozhestvennoy literatury. Moskva: Khudozhestvennaya literatura, 1979.

Lukach, Georgiy. „Roman kak burzhuaznaya epopeya”. Literaturnaya Entsyklopediya. Red. A.V. Lunacharskiy. T. 9. Moskva: Sovetskaya entsyklopediya, 1935. S. 795-832.

Lukach, Georgiy. „Teoriya romana: opyt istoriko-filosopfskogo isssledovaniya form bolshoi epiki”. Novoe literaturnoe obozreniye 9 (1994). S. 19-78.

Miy uchytel. Red. O. Yefimov. Kyiv: Veselka, 1977.

Mushketyk, Yuriy „Pozytsiya. Bila Tin”. Tvory [V 5 t.]. Yuriy Mushketyk. T. 3. Kyiv: Dnipro, 1988.

Nestaiko, Vsevolod. „Povist pro te, yak shkoliari pobuvaly v doistorychnomu chasi i chym tse zakinchylosia". Charionyi talisman. Vsevolod Nestaiko. Kyiv: Kraina Mriy, 2010. S. 143-284.

Nietzsche, Friedrich. „O polze I vrede istorii dlya zhizni”. Sochineniya [V 2 t.]. Friedrich Nietzsche. T. 1. Moskva: Mysl, 1990.

Obraz vraga. Red. N. Konradova. Moskva: OGI, 2005.

O'Dell Felicity Ann, red. Socialisation Through Children's Literature: The Soviet Example. New York and London: Cambridge University Press, 1978.

Pavlyshyn, Marko. „«Sobor» Olesia Honchara ta «Orlova Balka» Mykoly Rudenka: navkolyshnie seredovyshche yak tema i arhument". Kanon ta iconostas. Kyiv: Chas, 1997. S. 44-61.

Peroyi Vsesoyuznyi syezd pisatelei. Moskva: Gispolitizdar, 1934.

Postkolonializm. Heneratsii. Kultura. Red. T. Hundorova, A. Matusiak. Kyiv: Laurus, 2015.

Sadowski, Jakub. Rewolucja i kontrrewolucja obyczajów. Rodzina, prokreacja i przestrzeń życia w rosyjskim dyskursie utopijnym lat 20. i 30. XX wieku. Łódź: Wydawnictwo Ibidem, 2005.

Shchaslyvymy dorohamy. Red. B. Vasylevych. Lviv: Kameniar, 1965.

Shevelov, Yurii. Z istorii nezakinchenoi viiny. Red. O. Zabuzhko, L. Masenko. Kyiv: VD „Kyievo-Mohylianska akademiia", 2009.

Starovoit, Iryna. „Kotyhoroshko: pro dytynstvo v avtobiohrafichnii prozi Hryhora Tiutiunnyka”. Naukova zapysky NaUKMA. Filolohichni nauky 98 (2009). S. 59-64.

Stiazhkina, Olena. „Henderni vymiry radianskoi povsiakdennosti 1960 - seredyny 1980-kh rr.”. Kraieznavstvo. 3(2010). S. 214-223.

Zahrebelnyi, Pavlo. Rozhin. Kyiv: Radjansky pysmennyk, 1976. 